\title{
PHYSICOCHEMICAL AND RHEOLOGICAL PROPERTIES OF NON-FAT ICE CREAM
}

\author{
Karīna Silantjeva ${ }^{1}$, Jeḷena Zagorska ${ }^{2, \#}$, and Ruta Galoburda ${ }^{2}$ \\ ${ }^{1}$ LTD Ķeizarsils, Jaunbajāri, Salaspils Parish, Salaspils Municipality, LV-2117, LATVIA \\ ${ }^{2}$ Faculty of Food Technology, Latvia University of Life Sciences and Technologies, 22 Rĩgas Str., Jelgava, LV-3004, LATVIA \\ \# Corresponding author, jelena.zagorska@llu.Iv
}

Communicated by Tatjana K̦ince

\begin{abstract}
Ice cream is a popular dessert in Latvia. At present, however, as consumers are watching their calorie intake, ice cream is starting to lose its leading position due to rich fat content. Therefore, development of low-fat or non-fat ice cream can provide a good alternative for consumers. At the same time, reduced fat is a challenge to a producer because it strongly affects the texture and sensory properties of ice cream. The aim of the current study was to assess the physicochemical and rheological properties of whey-based non-fat ice cream, depending on the ingredients used in the formulation. In total, 11 ice cream formulations were developed and evaluated, with differing proportions of the main ingredients. Chemical composition, hardness (after $6 \mathrm{~h}$ of hardening and subsequent two-week storage), overrun and rheological properties were analysed. Higher amounts of pumpkin puree, sugar and whey concentrate decreased the hardness of ice cream, and increased the overrun. Thus, higher proportions of pumpkin puree and whey concentrate significantly influenced product formulation by stabilising and strengthening air cells. Both an increased proportion of pumpkin puree and gelatine increased complex viscosity. There was a positive correlation between carbohydrate content and ice cream hardness after two-week storage, as well as between protein content and complex viscosity.
\end{abstract}

Keywords: pumpkin puree, whey concentrate, gelatine, texture, overrun, viscosity.

\section{INTRODUCTION}

Ice cream is a popular dessert in Latvia. Traditionally, fat content in dairy ice cream formulation ranges from $5.0-15 \%$. Saturated fatty acids are associated with coronary heart disease, diabetes and other health problems (WHO, 2010). Nowadays, when consumers are watching their calorie intake (Da Silva et al., 2014), ice cream has started to lose its leading position due to being rich in fats. Therefore, low-fat and non-fat ice cream development can provide a good alternative for consumers.

Fat is of importance for the flavour and for the structure formed during freezing of ice cream. Reduced fat content is a challenge to a producer because it strongly affects the texture and sensory properties of ice cream, usually causing different defects such as coarseness, iciness, low overrun and empty taste (Jardines et al., 2020). Partially coalesced fat causes a fat network, which stabilises air bubble and foam structure in ice cream. Fat reduction increases formation of ice crystals and created a harder texture, which is not acceptable for consumers (Akbari et al., 2019). Therefore, ice cream manufacturers use fat replacers, stabilisers and various additives to improve the texture of the product.

Fat replacers are an alternative in ice cream production. They can improve the rheological and sensory properties of ice cream with reduced fat content. At the same time, the saturated fat concentration and energy value of the product would be lower. Fat replacers can be divided into three groups: plant-based lipids, protein-based additives (generally whey concentrate), and carbohydrate-based additives (modified starches, cellulose derivatives, inulin, pectin and others) (Akbari et al., 2019).

Stabilisers are ingredients responsible for the rheological properties of ice cream - large molecules, which interact with water. Stabilisers control properties of the unfrozen water, making ice cream smoother and lengthening the time for ice crystals to grow during storage (Park and Haenlein, 2013, pp. 435-457). 
Various natural functional ingredients are used to improve the nutraceutical value of ice cream. For example, ice creams are enriched with pomegranate by-products (Çam $e t$ al., 2013), processed ginger (Gabbi et al., 2018), quince seed (Kurt and Atalar, 2018), soy protein isolates (Liu et al. 2018), and agave fructans (Pintor-Jardines et al., 2018), which improve its technological and functional qualities. Whey proteins play various functions in ice cream formulation like emulsification of fat, increase of overrun and viscosity of the mix, creation of a desirable interfacial behaviour (Park and Haenlein, 2013, pp. 435-457), as well as promotion of functional properties of ice cream (Camargo et al., 2020). Pumpkin is a valuable ingredient for different food products, but traditionally it is not used in ice cream production. Pumpkin puree, being rich in pectin, could promote increase of water holding capacity, emulsification and/or gel formation, positively affecting the textural properties of ice cream (Akbari et al., 2019). Moreover, pumpkin is a fruit that is rich in carotenoids, lutein, violaxantine, phenols (Kampuse et al., 2019), and has a positive influence on lowering the glucose level in blood and in defence against cancer (Jacobo-Valenzuela et al., 2011).

It is expected that non-fat ice cream with satisfactory physicochemical properties, rheological and functional properties can be developed by selecting suitable ingredients (whey proteins, pumpkin puree, and gelatine), and their amounts and proportions in the formulation. Therefore, the aim of the current study was to assess the physicochemical and rheological properties of whey-based non-fat ice cream, depending on the ingredients used in the formulation.

\section{MATERIALS AND METHODS}

Materials. Ice cream mixes were produced from the following ingredients: cheese whey, whey concentrate (LTD Latvijas piens, Latvia), sugar (LTD Dansukker, Denmark), gelatine (LTD Orkla Foods Latvia, Latvia), pumpkin puree (100\% pumpkin, LTD Keefa, Latvia), mango puree (LTD Thomas Rink, Germany), citric acid (LTD Valezs, Latvia), and water. Nutritional values of the main ingredients are presented in Table 1. In total, 11 ice cream formulations were developed, with the aim to decrease sugar and fat content, at the same time obtaining satisfactory texture of the ice cream.

Preparation of ice cream. The used proportions whey (W), whey concentrate $(\mathrm{W})$, sugar $(\mathrm{S})$, gelatine $(\mathrm{G})$, and pumpkin puree $(\mathrm{P})$ in the ice cream samples are shown in Table 2.

In ice cream preparation, first, the dry components were weighted and mixed. Then the liquid and dry components were combined into ice cream mix. The obtained mix was pasteurised at $85{ }^{\circ} \mathrm{C}$ for $20 \pm 5 \mathrm{~s}$, then cooled down, and aged for $8 \mathrm{~h}$ at $5 \pm 1{ }^{\circ} \mathrm{C}$. The main technological operation - freezing, when ice cream mix is frozen and whipped at the same time, was performed using a Taylor model 142 ice cream machine (Taylor, USA) at $-8 \pm 2{ }^{\circ} \mathrm{C}$. Then, the ice cream was filled into plastic containers $(500 \mathrm{ml})$ and hardened at $-20 \pm 2{ }^{\circ} \mathrm{C}$ for $6 \mathrm{~h}$.
Table 1. Nutritional values of ingredients used in the ice cream formulations

\begin{tabular}{l|cc|c|c}
\hline \multirow{2}{*}{ Ingredients } & \multicolumn{4}{c}{ Content of nutrient, $\mathrm{g} \cdot 100 \mathrm{~g}^{-1}$} \\
\cline { 2 - 5 } & fat & carbohydrate & protein & ash \\
\hline Whey & 0.50 & 4.8 & 0.99 & 0.50 \\
Sugar & - & 100.0 & - & - \\
Gelatine & 0.10 & - & 85.63 & - \\
Whey concentrate & 0.50 & 21.2 & 4.01 & 0.90 \\
Pumpkin puree & 0.3 & 7.7 & 1.30 & 2.00 \\
Mango puree & - & 16.0 & 0.50 & 0.005
\end{tabular}

Table 2. Developed ice cream formulations

\begin{tabular}{l|c|c|c|c|c|c|c}
\hline \multirow{2}{*}{ Sample } & \multicolumn{7}{c}{ Ingredients, $\mathrm{g} \cdot \mathrm{kg}^{-1}$} \\
\cline { 2 - 8 } & whey & sugar & gelatine & $\begin{array}{c}\text { whey } \\
\text { concentrate }\end{array}$ & $\begin{array}{c}\text { pumpkin } \\
\text { puree }\end{array}$ & $\begin{array}{c}\text { mango } \\
\text { puree }\end{array}$ & $\begin{array}{c}\text { citric } \\
\text { acid }\end{array}$ \\
\hline S1 & 520 & 130 & 5 & 50 & 191 & 100 & 4 \\
S2 & 500 & 150 & 5 & 50 & 191 & 100 & 4 \\
S2 & 450 & 200 & 5 & 50 & 191 & 100 & 4 \\
G1 & 499 & 150 & 6 & 50 & 191 & 100 & 4 \\
G2 & 497 & 150 & 8 & 50 & 191 & 100 & 4 \\
G3 & 495 & 150 & 10 & 50 & 191 & 100 & 4 \\
W2 & 470 & 150 & 5 & 80 & 191 & 100 & 4 \\
W3 & 450 & 150 & 5 & 100 & 191 & 100 & 4 \\
P1 & 500 & 150 & 5 & 50 & 210 & 81 & 4 \\
P2 & 500 & 150 & 5 & 50 & 230 & 61 & 4 \\
P3 & 500 & 150 & 5 & 50 & 245 & 46 & 4
\end{tabular}

Evaluation of physicochemical parameters and energy value of ice cream. Chemical composition, nutritional value, hardness (after $6 \mathrm{~h}$ of hardening and subsequent $336 \mathrm{~h}$ of storage), overrun and rheological properties of the developed ice cream were analysed.

Protein content was determined according to ISO 8968-1:2014 using a Kjeltec ${ }^{\text {TM }} 2100$ (Foss, Denmark). Fat content was determined according to ISO 488:2008 using a centrifuge (Funke Gerber, Germany). Carbohydrates were determined by high-performance liquid chromatography (HPLC) (Shimadzu, Japan); the samples were filtered through a syringe filter with pore size of $0.45 \mu \mathrm{m}$. The content of individual sugars was determined using a LC 20 Prominence high-performance liquid chromatograph (Shimadzu, Japan), and total sugar concentration was estimated as a sum of individual sugars. Chromatographic parameters were set as follows: detector - refractive index RID-10A; column — Alltech NH2, $4.6 \mathrm{~mm} \cdot 250.0 \mathrm{~mm}, 5 \mu \mathrm{m}$; temperature $25^{\circ} \mathrm{C}$; isocratic elution regime, mobile phase A acetonitrile, B - deionised water (A70:B30); capacity of the injection sample $10 \mu \mathrm{L}$; total time of the analysis up to $15 \mathrm{~min}$; and flow rate $1.0 \mathrm{ml} \cdot \mathrm{min}^{-1}$. The acquired data were processed using Shimadzu LabSolutions software (LCsolution Version 1.21 SP1).

Energy value was calculated according to the EU Regulation (EU) No. 1169/2011 on the provision of food information to consumers entered into application on 13 December 2014. 
Analysis of ice cream hardness was performed by a penetration test using a TA.HD plus texture analyser (Stable Micro Systems, United Kingdom). The modified Varela et al. (2014) procedure was used. Ice cream samples (approximately $100 \mathrm{ml}$ each, in triplicate) were filled into plastic cups and placed in a freezer for 6 hours. For evaluation of hardening, ice cream samples were filled in $500 \mathrm{ml}$ plastic containers and placed in a freezer for $336 \mathrm{~h}$. Each sample container was taken out of the freezer $\left(-20^{\circ} \mathrm{C}\right)$ and tested immediately. The samples were penetrated to a depth of $15 \mathrm{~mm}$ with a 3-mm diameter cylindrical probe at a speed of $2 \mathrm{~mm} \cdot \mathrm{s}^{-1}$. The maximum force $(\mathrm{N})$ applied was used as a measure of hardness.

To evaluate overrun, the mass of a fixed volume $(50 \mathrm{ml})$ of aged ice cream mix was compared to the mass of the same volume of churned ice cream after freezing. The overrun was calculated according to the equation:

overrun $=$

$=\frac{\text { weight of aged ice cream mix }- \text { weight of ice cream }}{\text { weight of ice cream }} \times 100$

An oscillatory thermo-rheometry test for the ice cream samples was performed using a MSR-302 rheometer (Anton Paar, Switzerland) fitted with parallel plate geometry (diameter $25 \mathrm{~mm}$ ); the gap between the plates was adjusted to a constant value of $2 \mathrm{~mm}$. Prior to the oscillatory thermorheometry, a deformation amplitudes sweep test at a constant angular frequency $\left(\omega=10 \mathrm{~s}^{-1}\right)$ was carried out in order to determine the linear viscoelastic region (LVR). The changes in storage and loss modulus, loss factor and complex viscosity were determined in the temperature range from -6 to $10{ }^{\circ} \mathrm{C}$. The temperature interval was set at $1{ }^{\circ} \mathrm{C}$ per minute, data was recorded at 100 points, and thus the data point duration was $0.172 \mathrm{~min}$.

Statistical analysis. The obtained data were processed using Microsoft Excel (Microsoft Office Enterprise 2007, License: Shareware N/A); differences among results were considered significant if $p$-value $<0.05$. Significant differences among ice cream sample attributes were determined by the Tukey's test. For the interpretation of the results, it was assumed that $\alpha=0.05$ with $95 \%$ confidence. In addition, correlations between composition and physico-chemical parameters of ice cream were evaluated, considering $\mathrm{r} \geq$ 0.8 strong correlation, $0.5<\mathrm{r}<0.8$ moderate correlation.

\section{RESULTS}

Chemical composition. The chemical composition of the developed ice creams is shown in Table 3. Among the developed ice cream samples, significantly higher $(p<0.05)$ carbohydrate content was detected in S3 samples compared to other samples. By protein content our ice cream samples can be divided into two groups: significantly lower $(p<$ $0.05)$ protein content was detected in control, S2, W2, and all $\mathrm{P}$ samples, and significantly higher $(p<0.05)$ in samples
Table 3. Nutritional and energy value of the developed ice cream

\begin{tabular}{|c|c|c|c|c|c|}
\hline \multirow{2}{*}{$\begin{array}{l}\text { Sample } \\
\text { code }\end{array}$} & \multicolumn{5}{|c|}{ Value per $100 \mathrm{~g}$ of ice cream } \\
\hline & $\begin{array}{r}\text { fat, } \\
\mathrm{g}\end{array}$ & \begin{tabular}{|c|} 
carbohydrate, \\
$\mathrm{g}$
\end{tabular} & $\begin{array}{c}\text { protein, } \\
\mathrm{g}\end{array}$ & $\begin{array}{c}\text { solids, } \\
\mathrm{g}\end{array}$ & $\begin{array}{c}\text { energy } \\
\text { value, } \mathrm{kJ}\end{array}$ \\
\hline S1 & $0.34 \mathrm{a}, \mathrm{b}$ & $19.63 \mathrm{f}$ & $1.44 \mathrm{~d}, \mathrm{e}$ & $21.41 \mathrm{j}$ & $370.77 \mathrm{j}$ \\
\hline $\mathrm{S} 2$ & $0.33 \mathrm{~b}, \mathrm{c}$, & $21.53 \mathrm{c}, \mathrm{d}, \mathrm{e}$ & $1.42 \mathrm{~d}, \mathrm{e}$ & $23.29 \mathrm{f}, \mathrm{g}$ & $402.36 \mathrm{f}$ \\
\hline S3 & $0.31 \mathrm{c}$ & $26.29 \mathrm{a}$ & $1.37 \mathrm{e}$ & $27.97 \mathrm{a}$ & 481.69 a \\
\hline G1 & $0.33 \mathrm{~b}, \mathrm{c}$, & $21.53 \mathrm{c}, \mathrm{d}, \mathrm{e}$ & $1.51 \mathrm{c}, \mathrm{d}$ & $23.36 \mathrm{e}, \mathrm{f}$ & 403.89 e \\
\hline G2 & $0.33 \mathrm{~b}, \mathrm{c}$, & $21.52 \mathrm{~d}, \mathrm{e}$ & $1.68 \mathrm{~b}$ & $23.52 \mathrm{~d}, \mathrm{e}$ & $406.61 \mathrm{c}$ \\
\hline G3 & $0.33 \mathrm{~b}, \mathrm{c}$, & $21.51 \mathrm{~d}, \mathrm{e}$ & $1.85 \mathrm{a}$ & $23.68 \mathrm{~d}$ & $409.33 \mathrm{~b}$ \\
\hline W2 & $0.33 \mathrm{~b}, \mathrm{c}$, & $22.02 \mathrm{~b}, \mathrm{c}$ & $1.51 \mathrm{c}, \mathrm{d}$ & $23.87 \mathrm{c}$ & $412.22 \mathrm{~d}, \mathrm{e}$ \\
\hline W3 & $0.33 \mathrm{~b}, \mathrm{c}$, & $22.35 \mathrm{~b}$ & $1.57 \mathrm{c}$ & $24.26 \mathrm{~b}$ & $418.85 \mathrm{~d}$ \\
\hline P1 & $0.34 \mathrm{a}, \mathrm{b}$ & $21.37 \mathrm{~d}, \mathrm{e}$ & $1.44 \mathrm{~d}, \mathrm{e}$ & $23.15 \mathrm{~g}, \mathrm{~h}$ & $400.35 \mathrm{~g}$ \\
\hline P2 & $0.34 \mathrm{a}, \mathrm{b}$ & $21.21 \mathrm{~d}, \mathrm{e}$ & $1.45 \mathrm{~d}, \mathrm{e}$ & $23.00 \mathrm{~h}, \mathrm{i}$ & $397.80 \mathrm{~h}$ \\
\hline P3 & $0.35 \mathrm{a}$ & $21.08 \mathrm{e}$ & $1.47 \mathrm{~d}, \mathrm{e}$ & $22.90 \mathrm{i}$ & $396.30 \mathrm{i}$ \\
\hline
\end{tabular}

a,b,c, Means with the same letters within a column are not significantly different $(p>0.05)$.

Table 4. Hardness and overrun of non-fat ice cream

\begin{tabular}{c|c|c|c}
\hline \multirow{2}{*}{ Sample code } & \multicolumn{2}{|c|}{ Hardness, N } & \multirow{2}{*}{ Overrun, \% } \\
\cline { 2 - 3 } & after 6 h & after $336 \mathrm{~h}$ & \\
\hline \multirow{2}{*}{ S1 } & $1.04 \mathrm{~d}, \mathrm{e}$ & $554.41 \mathrm{a}$ & $31.86 \mathrm{~d}$ \\
S2 & $0.83 \mathrm{e}$, & $242.90 \mathrm{f}, \mathrm{g}$ & $20.38 \mathrm{j}$ \\
S3 & f0.41 & $213.40 \mathrm{~g}, \mathrm{~h}, \mathrm{i}$ & $25.03 \mathrm{i}$ \\
G1 & $1.12 \mathrm{~d}, \mathrm{e}$ & $289.04 \mathrm{~d}, \mathrm{e}$ & $40.50 \mathrm{c}$ \\
G2 & $0.65 \mathrm{e}, \mathrm{f}$ & $385.58 \mathrm{c}$ & $27.19 \mathrm{~h}$ \\
G3 & $0.97 \mathrm{~d}, \mathrm{e}$ & $203.33 \mathrm{~h}, \mathrm{i}$ & $31.40 \mathrm{e}$ \\
W2 & $2.46 \mathrm{~b}$ & $305.48 \mathrm{~d}$ & $27.58 \mathrm{~g}$ \\
W3 & $1.81 \mathrm{c}$ & $196.06 \mathrm{i}$ & $30.32 \mathrm{f}$ \\
P1 & $11.13 \mathrm{a}$ & $436.69 \mathrm{~b}$ & $18.91 \mathrm{k}$ \\
P2 & $1.46 \mathrm{c}, \mathrm{d}$ & $265.52 \mathrm{e}, \mathrm{f}$ & $43.92 \mathrm{a}$ \\
P3 & $1.18 \mathrm{~d}, \mathrm{e}$ & $230.70 \mathrm{~g}, \mathrm{~h}$ & $42.92 \mathrm{~b}$
\end{tabular}

$\overline{\text { Data are presented }}$ as mean values ( $n=10$ for hardness, $n=3$ for overrun). a,b,c, Means with the same letters within a column are not significantly different $(p>0.05)$

with gelatine $(\mathrm{G})$ and whey concentrate $(\mathrm{W})$ used in formulations.

Hardness and overrun. Hardness of the non-fat ice cream samples after 6-hour and 366-hour storage is presented in Table 4. The ingredients incorporated in the ice cream formulations demonstrated varied influence on the hardness. Among the ice cream samples analysed, the lowest hardness occurred in the sample with the highest sugar content (S3) and in the sample with medium gelatine content (G2).

Regardless of the ingredients used in the ice cream formulation, its hardness increased substantially from 6 hours to 336 hours of frozen storage. After 336 hour storage, the lowest hardness was observed in samples S3, G3, and W3. The hardness of ice cream during storage can be affected with increased proportion of sugar, whey concentrate and gelatine in the ice cream formulations. 
Overrun is a very important factor, which should be considered during ice cream production, because it directly affects sensory qualities and consumer acceptance. In the current study, overrun was affected by formulation of the ice cream (Table 4). Overrun in the ice cream ranged from $18.91 \%$ (P1) to $43.92 \%$ (P2). Taking into account that the fat content in the ice cream samples was very low $(0.31 \%$ to $0.35 \%$ ), it can be concluded that the achieved overrun for non-fat ice cream was high.
Rheological properties. The storage and loss moduli measured by oscillatory thermo-rheometry are presented in Fig. 1. The temperature zone from $-6{ }^{\circ} \mathrm{C}$ till $-1{ }^{\circ} \mathrm{C}$ demonstrates ice cream melting. According to Wildmoser et al. (2004), a steep slope corresponds to a more pronounced sensorial impression of coldness. Among samples with varied sugar content, the steepest slope was observed for sample S1, which contained the highest amount of water and the smallest content of sugar. This may lead to an icy microstructure
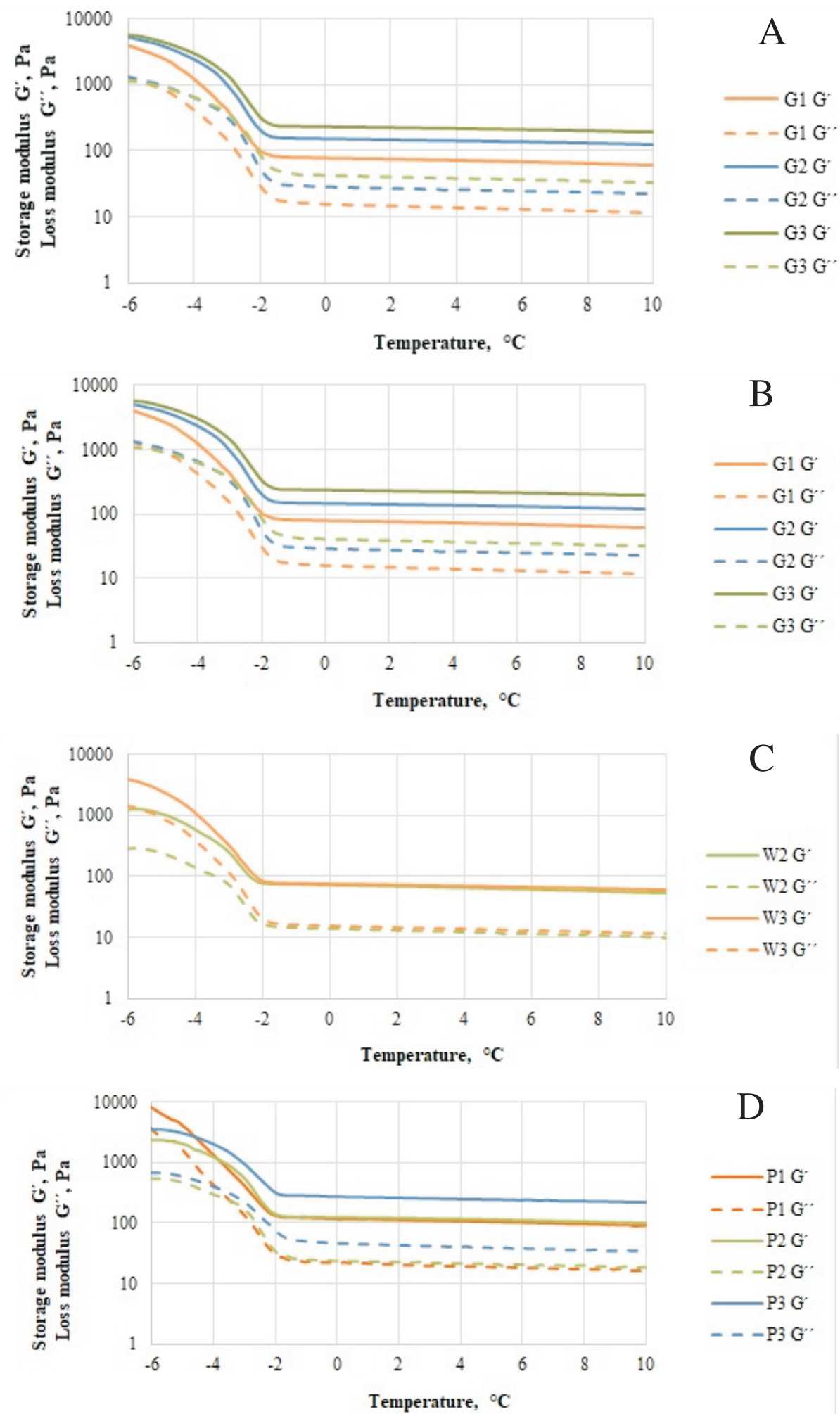

$\mathrm{B}$

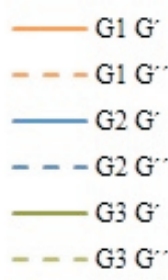

C
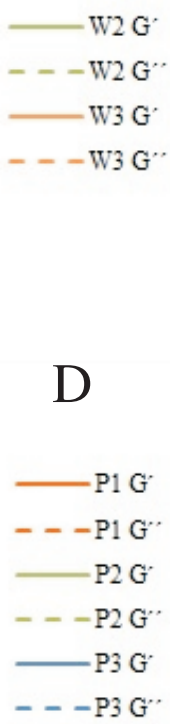

$--\mathrm{P} 3 \mathrm{G}^{\prime}$
Fig. 1. Storage modulus G' (filled markers) and loss modulus G' (open markers) measured in a temperature sweep test depending on variable ingredient proportions in the formulations: A - varied sugar content (S); B - varied gelatine content (G); C varied whey concentrate content (W), D varied pumpkin puree content $(\mathrm{P})$. 
Table 5. Rheological properties of non-fat ice cream

\begin{tabular}{c|c|c|c|c}
\hline \multirow{2}{*}{$\begin{array}{c}\text { Sample } \\
\text { code }\end{array}$} & $\begin{array}{c}\text { Complex } \\
\text { viscosity at } \\
10{ }^{\circ} \mathrm{C}, \mathrm{Pa} \mathrm{s}\end{array}$ & $\begin{array}{c}\text { Moduli and loss factor at }-6{ }^{\circ} \mathrm{C} \\
\text { modulus, } \\
\text { Pa }\end{array}$ & $\begin{array}{c}\text { loss modulus, } \\
\mathrm{Pa}\end{array}$ & loss factor \\
\hline S1 & $3.97 \mathrm{~g}$ & $15530 \mathrm{a}$ & $5505 \mathrm{a}$ & $0.354 \mathrm{~b}$ \\
$\mathrm{~S} 2$ & $7.84 \mathrm{e}$ & $2236 \mathrm{f}$ & $550 \mathrm{e}$ & $0.246 \mathrm{~d}$ \\
$\mathrm{~S} 3$ & $6.49 \mathrm{e}, \mathrm{f}$ & $607 \mathrm{~h}$ & $169 \mathrm{f}$ & $0.279 \mathrm{c}$ \\
G1 & $6.09 \mathrm{f}$ & $4009 \mathrm{~d}$ & $1352 \mathrm{c}$ & $0.337 \mathrm{~b}$ \\
G2 & $12.37 \mathrm{c}$ & $5228 \mathrm{c}$ & $1316 \mathrm{c}$ & $0.252 \mathrm{~d}$ \\
G3 & $20.05 \mathrm{~b}$ & $5582 \mathrm{c}$ & $1113 \mathrm{~d}$ & $0.199 \mathrm{f}$ \\
W2 & $5.29 \mathrm{f}, \mathrm{g}$ & $1242 \mathrm{~g}$ & $286 \mathrm{~d}$ & $0.230 \mathrm{e}, \mathrm{d}$ \\
W3 & $5.95 \mathrm{f}$ & $4009 \mathrm{~g}$ & $1422 \mathrm{c}$ & $0.355 \mathrm{~b}$ \\
P1 & $9.57 \mathrm{~d}$ & $8428 \mathrm{~b}$ & $3804 \mathrm{~b}$ & $0.451 \mathrm{a}$ \\
P2 & $9.91 \mathrm{~d}$ & $2386 \mathrm{f}$ & $532 \mathrm{e}$ & $0.223 \mathrm{e}$ \\
P3 & $22.52 \mathrm{a}$ & $3551 \mathrm{e}$ & $698 \mathrm{e}$ & $0.197 \mathrm{f}$
\end{tabular}

a, b, c, means with the same letters within a column are not significantly different $(p>0.05)$.

with an increased level of ice crystal connectivity. Increased amounts of gelatine, whey concentrate and pumpkin puree caused reducing steepness of the slope.

The lowest values of G' and G' 'were observed at temperatures above $0{ }^{\circ} \mathrm{C}$. At these conditions, all ice is melted, and therefore compounds integrated in the ice cream formulation have the greatest influence on the rheological properties.

Both increased amount of pumpkin puree (samples P1-P3) and gelatine (samples G1-G3) increased complex viscosity (Table 5). However, viscosity was little affected by the content of the whey concentrate added (samples W1-W2). An increased proportion of pumpkin puree (samples P1-P3) changed the value of storage and loss modulus at $-6{ }^{\circ} \mathrm{C}$. The highest storage and loss modulus among ice creams studied was for the sample containing the smallest amount of sugar additive (S1), which was followed by sample with the lowest pumpkin puree content (P1).

\section{DISCUSSION}

Ice cream is a complex frozen food system that contains proteins, crystallised fat and water, air, minerals, additives, and sweeteners (Kaleda et al., 2018). Traditional ice cream contains fat $(5-15 \%)$, protein $(4-5 \%)$, lactose $(5-7 \%)$, other sugars $(12-16 \%)$, stabilisers, emulsifiers $(0.5 \%)$, total solids (28-40\%), and water (60-72\%) (Clarke, 2012). Compared to the traditional ice cream, the non-fat ice-cream developed in the current study contained significantly $(p<0.05)$ lower concentration of solids (from 21.41 to $27.97 \mathrm{~g} \cdot 100 \mathrm{~g}^{-1}$ ), fat ( 0.31 to $0.35 \mathrm{~g} \cdot 100 \mathrm{~g}^{-1}$ ) and protein (from 1.22 to 1.85 $\mathrm{g} \cdot 100 \mathrm{~g}^{-1}$ ). The developed ice cream can be called a non-fat ice cream, because the concentration of fat is less than $0.5 \%$ (Park and Haenlein, 2013, pp. 435-457) (Table 3). According to the data from Park and Haenlein (2013) research, non-fat ice cream contains $35 \%$ total solids, which is significantly $(p<0.05)$ higher compared to the ice cream developed in our study.
As one of the main tasks of the current study was to decrease fat content in the product, milk or/and cream was replaced by whey, which was the base of formulation. Milk solids contribute to the flavour, and are responsible for increased viscosity (Walstra et al., 2005). Compared with traditional ice cream, low-fat and non-fat ice creams have problems regarding poor flavour and textural qualities (Akalin et al., 2008; Akbari et al., 2019). According to Arbuckle and Marshall (2020), non-fat or low-fat ice cream typically contains higher carbohydrate concentration, which compensates for required solids content. To ensure good textural properties of ice cream with low total solids concentration, pumpkin puree, gelatine and whey protein concentrate were used in the formulations (Table 2).

Structure is one of the main parameters determining consumer acceptance of an ice cream. The structure of an ice cream is described as a three-component foam made up of a network of fat globules and ice crystals dispersed in a high viscosity aqueous phase. The air volume in ice cream can range from high, more than $50 \%$, to low $10-15 \%$ (Goff, 2002). In the case of non-fat and low-fat ice creams, the fat globule network can either be disrupted or absent and this could seriously affect the texture of the product (Aime et al., 2001; McGhee et al., 2015). The hardness of ice cream can be affected by the formulation: content of solids, sugars, fats, proteins, amount and characteristics of the used emulsifiers and stabilisers. All these factors affect the amount of free water, as well as the freezing temperature of the ice cream. Our study revealed positive strong to medium correlation between carbohydrate content and ice cream hardness after $336 \mathrm{~h}$ storage $(\mathrm{r}=0.710)$, as well as between protein content and complex viscosity $(r=0.503)$. Weak negative correlation was found between carbohydrate content and storage modulus $(\mathrm{r}=-0.617)$, and carbohydrate content and loss modulus $(\mathrm{r}=-0.533)$. Another factor negatively affecting ice cream structure and hardness, is storage time (McGhee et al 2015), as also found in our study.

Increased proportion of sugar in the formulation was associated with significantly lower $(p<0.05)$ hardness of ice cream sample S3 compared to S1 (Table 4). The total solids content can also affect ice cream hardness (Akbari et al., 2019), but in the present study this parameter had no significant effect $(p>0.05)$. This can be explained by the high proportion of sugar in solids, which decreased the hardness of ice cream. Increased sucrose content reduces ice crystal size (Arbuckle and Marshall, 2000) and this sugar positively influences consistency of the ice cream, making it softer (Chorafas, 2015). Decrease of sugar content in the formulation positively influenced overrun of ice cream; in sample $\mathrm{S} 1$ it was significantly higher $(p<0.05)$, compared to the sample S3 and S2. In the current study, other components in formulations and their proportion influenced the overrun of the ice cream samples analysed.

Proteins have two main functions in the ice cream production. First, as a surface active component it stabilises water continuous emulsion and foam, increasing viscosity, and second, they contribute to the flavour of product (Chorafas, 
2015). Two protein sources, gelatine and whey concentrate, were used in the current study.

An increased amount of gelatine in formulations $(p<0.05)$ influenced hardness of ice cream. The highest content of gelatine used in the current research (sample G2 and G3) significantly $(p<0.05)$ increased complex viscosity of the ice cream, which may be associated with increased sensorial creaminess (Wildmoser et al., 2004). It should be noted that between samples with different gelatine content, significant differences $(p<0.05)$ were found for ice cream hardness after $6 \mathrm{~h}$. The effect of amount of gelatine on ice cream hardness during $336 \mathrm{~h}$ storage was different. The highest content of gelatine $(\mathrm{G} 3)$ used in the current research was associated with significantly softer ice cream $(p<0.05)$ compared to the G1 and G2 samples.

The proportion of gelatine in formulations had significant effect on overrun; sample G1 showed significantly higher overrun $(p<0.05)$ compared to the samples G2 and G3. Such results are contradictory to a previous study (Mahdian, 2013), where higher overrun was associated with higher protein concentration in ice cream, but are in agreement with another study (Daw and Hartel, 2015).

Regarding content of whey concentrate, significantly higher $(p<0.05)$ hardness after $6 \mathrm{~h}$ was found in sample W2 with a lower content of protein, compared to sample W3. It should be noted that not only the specific fat replacer, but also the proportions applied in a formulation are significant for obtaining ice cream with acceptable quality. An increased amount of whey concentrate significantly decreased $(p<0.05)$ hardness of ice cream during storage. As a positive tendency, whey concentrate stabilised ice cream structure during storage protecting it from increased hardness, which can have a positive effect on consumer's choice. Whey concentrate, rich in whey proteins, helps to ensure air bubble structure, covering it with membrane (Park and Haenlein, 2013, pp. 435-457). An increased proportion of whey protein significantly $(p<0.05)$ promoted overrun of ice cream.

The removal or change in the proportion of one ingredient may affect the physical properties and structure of the ice cream, which was observed in the current study. Higher protein content resulted in softer texture of ice cream. However, the concentration and characteristics of protein had significant effect as well. Comparing $\mathrm{G}$ and $\mathrm{W}$ samples, better rheological properties (lower hardness, higher overrun) were obtained with use of gelatine as a stabiliser in ice cream production.

There are different opinions about protein and its influence on the hardness of ice cream. Some studies (Wille et al 2012) found that proteins have a positive influence on ice cream structure. The current found that protein had a positive influence on ice cream hardness. The samples with higher protein content (G3 and W3) had softer texture after 336 hours of storage.
We observed that the source of protein in ice cream mixture affects overrun, which is in agreement with other studies (Flores and Goff, 1999).

Higher pumpkin puree content in samples P2 and P3 was associated with significantly lower hardness $(p<0.05)$ of ice cream, compared to sample P1. During storage, the smallest changes were found for ice cream sample P1, compared to P2 and P3, but higher amount of pumpkin puree continued to reduce the hardness of ice cream. Pumpkin is rich in pectin (Yoo et al., 2012; Ali, 2015), which may increase water holding capacity, emulsification and gel formation (Akbari et al., 2019). Furthermore, gel formation of pumpkin pectin in very low concentrations can provide good gelation properties (Ptitchkina et al. 1994).

The amount of pumpkin puree had a significant effect on overrun. The highest overrun $(p<0.05)$ was observed in samples P2 and P3. Pumpkin puree in a concentration from 23 to $24.5 \%$ significantly increased $(p<0.05)$ the overrun of ice cream.

The ice cream samples with higher overrun had lower hardness, especially after hardening for 336 hours $(r=-0.655)$. Previously (Rolon et al., 2017), it was also observed that lower overrun in ice cream leads to a decrease in its hardness.

\section{CONCLUSIONS}

Non-fat ice cream structure and rheological properties can be improved by applying fat-replacers: gelatine, pumpkin puree, and whey concentrate.

An increased proportion of pumpkin puree, gelatine and whey concentrate decreased hardness of ice cream after $6 \mathrm{~h}$ hardening. After $336 \mathrm{~h}$ of storage, the softest samples were the ones with the highest content of carbohydrates and solids.

Significantly higher $(p<0.05)$ overrun was obtained when higher content of pumpkin puree was used in the formulation.

\section{REFERENCES}

Aime, D., Arntfield, S., Malcolmson, L., Ryland, D. (2001). Textural analysis of fat reduced vanilla ice cream products. Food Res. Int., 34 (2-3), 237-246.

AkalIn, A. S., Karagözlü, C., Ünal, G. (2008). Rheological properties of reduced-fat and low-fat ice cream containing whey protein isolate and inulin. Eur. Food Res. Technol., 227 (3), 889-895.

Akbari, M., Eskandari, M. H., Davoudi, Z. (2019). Application and functions of fat replacers in low-fat ice cream: A review. Trends Food Sci. Technol., 86, 34-40.

Arbuckle, W. S., Marshall, R. T. (2000). Ice Cream. Springer. 483 pp.

Çam, M., Erdogan, F., Aslan, D., Dinç, M. (2013). Enrichment of functional properties of ice cream with pomegranate by-products. J. Food Sci., 78 (10), 1543-1550. 
Camargo, L. da R., Doneda, D., Oliveira, V. R. (2020). Whey protein ingestion in elderly diet and the association with physical, performance and clinical outcomes. Exper. Gerontol., 137, 110936.

Chorafas, D. N. (2015). Science and Technology. Springer Cham. 207 pp.

Clarke, C. (2012). The Science of Ice Creame. $2^{\text {nd }}$ edition. CPJ Group, Croydon, UK. 213 pp.

Da Silva, V. M., Minim, V. P. R., Ferreira, M. A. M., Souza, P. H. de P., Moraes, L. E. da S., Minim, L. A. Ō. (2014). Study of the perception of consumers in relation to different ice cream concepts. Food Qual. Prefer., 36, $161-168$

Daw, E., Hartel, R. W. (2015). Fat destabilization and melt-down of ice creams with increased protein content. Int. Dairy J., 43, 33-41.

Mahdian, E., Karazhian, R. (2013). Effects of fat replacers and stabilizers on rheological, physicochemical and sensory properties of reduced-fat ice cream. J. Agricult. Sci. Technol., 15, 1163-1174.

Flores, A. A., Goff, H. D. (1999). Ice crystal size distributions in dynamically frozen model solutions and ice cream as affected by stabilizers. J. Dairy Sci., 82 (7), 1399-1407.

Gabbi, D. K., Bajwa, U., Goraya, R. K. (2018). Physicochemical, melting and sensory properties of ice cream incorporating processed ginger (Zingiber officinale). Int. J. Dairy Technol., 71 (1), 190-197.

Goff, H. D. (2002). Formation and stabilisation of structure in ice-cream and related products. Curr. Opin. Colloid Interface Sci., 7 (5-6), 432-437.

Jacobo-Valenzuela, N., Zazueta-Morales, J. de, Gallegos-Infante, J. A., Aguilar-Gutierrez, F., Camacho-Hernịndez, I. L., Rocha-Guzman, N. E., Gonzalez-Laredo, R. F. (2011). Chemical and physicochemical characterization of winter squash (Cucurbita moschata D.). Notulae Botanicae Horti Agrobotanici Cluj-Napoca, 39 (1), 34-40.

Jardines, A. P., Arjona-Román, J. L., Severiano-Pérez, P., TotosausSánchez, A., Fiszman, S., Escalona-Buendía, H. B. (2020). Agave fructans as fat and sugar replacers in ice cream: Sensory, thermal and texture properties. Food Hydrocolloids, 108, 106032.

Kaleda, A., Tsanev, R., Klesment, T., Vilu, R., Laos, K. (2018). Ice cream structure modification by ice-binding proteins. Food Chem., 246, $164-171$.

Kampuse, S., Tomsone, L., Klava, D., Ozola, L., Galoburda, R. (2019). The influence of processing and storage conditions on quality parameters of pumpkin puree. 13th Baltic Conference on Food Science and Technology "Food. Nutrition. Well-being", pp. 137-142. DOI: 10.22616/FoodBalt.2019.013.

Received 22 March 2021

Accepted in the final form 17 November 2021
Kurt, A., Atalar, I. (2018). Effects of quince seed on the rheological, structural and sensory characteristics of ice cream. Food Hydrocolloids, 82, $186-195$.

Liu, R., Wang, L., Liu, Y., Wu, T., Zhang, M. (2018). Fabricating soy protein hydrolysate/xanthan gum as fat replacer in ice cream by combined enzymatic and heat-shearing treatment. Food Hydrocolloids, 81, 39-47.

McGhee, C. E., Jones, J. O., Park, Y. W. (2015). Evaluation of textural and sensory characteristics of three types of low-fat goat milk ice cream. Small Rumin.Res., 123 (2-3), 293-300.

Park, Y. W., Haenlein, G. F. W. (2013). Milk and Dairy Products in Human Nutrition: Production, Composition and Health. Wiley Blackwell, UK, 738 pp.

Pintor-Jardines, A., Arjona-Román, J. L., Totosaus-Sánchez, A., SeverianoPérez, P., González-González, L. R., Escalona-Buendia, H. B. (2018). The influence of agave fructans on thermal properties of low-fat, and low-fat and sugar ice cream. LWT - Food Science and Technology, 93, 679-685.

Ptitchkina, N. M., Danilova, I. A., Doxastakis, G., Kasapis, S., Morris, E. R (1994). Pumpkin pectin: Gel formation at unusually low concentration. Carbohydr. Polymers, 23 (4), 265-273.

Rolon, M. L., Bakke, A. J., Coupland, J. N., Hayes, J. E., Roberts, R. F. (2017). Effect of fat content on the physical properties and consumer acceptability of vanilla ice cream. J. Dairy Sci., 100 (7), 5217-5227.

Seleim, M. A. A., Ali, H. M., Hassan, M. A. M. (2015). Comparative study on the $\beta$-carotene, $\alpha$-tocopherol and pectin values from three cultivars of pumpkin (Cucurbita maxima). World J. Dairy Food Sci., 10 (2), 132-140.

Varela, P., Pintor, A., Fiszman, S. (2014). How hydrocolloids affect the temporal oral perception of ice cream. Food Hydrocolloids, 36, 220-228.

Walstra, P., Walstra, P., Wouters, J. T. M., Geurts, T. J. (2005). Dairy Science and Technology. CRC Press. 808 pp.

WHO. (2010). Global Health Indicator Tables and Footnotes Part 2. World Health Statistics.

https://www.who.int/whosis/whostat/EN_WHS10_Part2.pdf (accessed 01.02.2021)

Wildmoser, H., Scheiwiller, J., Windhab, E. J. (2004). Impact of disperse microstructure on rheology and quality aspects of ice cream. LWT - Food Science and Technology, 37 (8), 881-891.

Wille, H. J. E., Viera, J. B., De Kruif, G. G., Floris, T. A. G., Slangen, K. J. (2012). Patent: Ice-structuring peptides of lactic acid. EP1917865. Spain.

Yoo, S. H., Lee, B. H., Lee, H., Lee, S., Bae, I. Y., Lee, H. G., Fishman, M L., Chau, H. K., Savary, B. J., Hotchkiss, A. T. (2012). Structural characteristics of pumpkin pectin extracted by microwave heating. J. Food Sci., 77 (11), C1169-73.

\section{BEZTAUKU SALDĒJUMA FIZIKĀLI K̦ĪMISKĀS UN REOLOG̣ISKĀS ĪPAŠIBAS}

Saldējums ir viens no populārākajiem desertiem Latvijā. Tomēr mūsdienās, kad patērētāji aizvien biežāk seko līdzi uzṇemto uzturvielu daudzumam, saldējums sāk zaudēt savas līdera pozīcijas augstā tauku satura dēḷ. Tāpēc beztauku saldējuma izstrāde var būt alternatīvs risinājums. Tauku satura samazināšana saldējumā ir izaicinājums ražotājiem, jo tā būtiski ietekmē produkta struktūru un sensorās îpašỉbas. Darba mērkị ir vērtēt uz sūkalu bāzes gatavota beztauku saldējuma fizikāli kīmiskās un reoloğiskās īpašības atkarībā no izmantoto sastāvdaḷu daudzuma receptūrā. Mainot sastāvdaḷu proporcijas maisījumā, kopumā tika izveidotas un vērtētas 11 saldējuma receptūras. Pētìjuma laikā tika analizēts saldējuma ķīmiskais sastāvs, cietība (pēc sešām stundām un pēc divām uzglabāšanas nedẹ̄̂ām), uzputojamība un reoloǵiskās īpašības. Palielinot kiirbju biezeṇa, cukura un sūkalu koncentrāta daudzumu receptūrā, samazinājās saldējuma cietība un palielinājās tā uzputojamība. Lielāka kirbju biezeña un sūkalu koncentrāta proporcija būtiski ietekmēja saldējuma struktūru, stabilizējot un nostiprinot gaisa pūslīšu apvalkus. Gan paaugstināts k̦irbju biezeņa, gan želatīna īpatsvars receptūrā palielināja produkta viskozitāti. Pētījumā konstatēta pozitīva korelācija gan starp og̣̣hidrātu saturu saldējumā un cietību pēc divām uzglabāšanas nedēḷām, gan starp olbaltumvielu saturu un viskozitāti. 